\title{
ABOUT THE CURRICULUM CONTENTS STRUCTURE OF TECHNICAL SUBJECTS IN PRIMARY EDUCATION - GENERALIZATIONS
}

\section{Jiří KROPÁČ st. - Jiří KROPÁČ ml. - Jitka PLISCHKE}

\begin{abstract}
The artical is based on the results of J. Bruner's research on the structure of curriculum contents as presented by M. Pasch. The authors present the initial concept of the so-called generalizations for the technical subjects instruction in primary education. They also deal with connections of generalizations and the relationship of facts and generalizations from the viewpoint of generalizations accuracy.
\end{abstract}

Key words: Technical subjects, instruction, curriculum contents structure, generalization, facts.

\section{KE STRUKTUŘE OBSAHU UČIVA TECHNICKÝCH PŘEDMĚTŮ V ZÁKLADNÍM VZDĚLÁVÁNÍ - GENERALIZACE}

Resumé: Stat' vychází z výsledků výzkumi̊ J. Brunera o struktuře obsahu učiva, jak je prezentuje M. Pasch. Autoři predkládaji výchozi návrh tzv. generalizaci pro výuku technických predmètù v základním vzdèlávání. Zabývají se rovněž souvislostmi formulace generalizací a vztahem faktů a generalizací z hlediska správnosti generalizací.

Kličová slova: Technické předměty, výuka, struktura obsahu učiva, generalizace, fakta.

\section{1 Úvod}

Ve výuce prováděné podle Rámcových vzdělávacích programů (dále RVP) jsou úsilí školy, obsah vzdělávání a vzdělávací aktivity zaměřeny k osvojování a rozvíjení klíčových kompetencí. Učivo je tedy prostředkem k osvojení činnostně chápaných výstupů směřujících ke klíčovým kompetencím (1, s. 14). Značná část tvorby struktury obsahu učiva je přenesena na školy, nebot' jsou zodpovědné za zpracování ŠVP. Mnohé $\mathrm{z}$ nich si počínají promyšleně, viz mj. mapy učiva využívané (2) aj.

Vzdělávací oblast RVP pro základní vzdělávání (dále ZV) Člověk a svět práce obsahuje tematické okruhy zaměřené technicky, jsou však různorodé a ani nemusí být probírány všechny (1, s. 81-86). Zde je tedy náročnost vytváření struktury obsahu učiva možno spatřovat $\mathrm{v}$ návaznostech $\mathrm{s}$ učivem dalších vzdělávacích oblastí (vyučovacích předmětů) i v optimálním rozpracování struktury učiva technicky zaměřeného tematického okruhu včetně koordinace struktury obsahu těchto tematických okruhů. Stat' je zacílena na využití teorie struktury obsahu učiva pro výuku technických předmětů $\mathrm{v}$ základním vzdělávání a na souvislosti vytváření generalizací pro tuto výuku.

Pojem struktura obsahu učiva lze sice chápat úzce, jako vhodnou návaznost témat a dalších součástí obsahu, zásluhou J. Brunera a publikovaným aplikacím jeho výsledků, mj. (3, s. 52-86), je však tento pojem chápán vícerozměrně. Potom jde o strukturu fakt, pojmů a generalizací tématu ve vzájemné souvislosti těchto tří kategorií vytvářené na základě generalizací a rovněž ve vhodné návaznosti témat a dále jejich „obsahových prvků“. Každé vyučované téma má tedy podle J. Brunera strukturu skládající se ze tří prvků, jsou to generalizace, pojmy a fakta a přestože jsou všechny tyto prvky důležité, pro uspořádání obsahu učiva je nejvýznamnější pochopení generalizací. Generalizace vyplývají tedy z logiky obsahu a měly by strukturu při didaktickém zpracování obsahu předurčovat. Zaměření výuky na generalizace a pojmy, nikoliv na jednotlivá, třeba i potřebná fakta, považoval J. Bruner za nezbytné.

$\mathrm{Na}$ základě RVP pro ZV a koncepčně pojatých publikací usilujeme $\mathrm{v}$ této stati o vytvoření generalizací pro výuku technických předmětů $\mathrm{V}$ ZV. Formulace generalizací představují jakési významné principy činností s technikou, odpovídají tedy zákonitostem techniky, požadavkům na správnou činnost atp. Generalizace mohou být pro více tematických oblastí RVP pro ZV společné, tak působí jako sjednocující činitelé obsahu. Jak jsme se přesvědčili, uplatnění této teorie pro zpracování technického obsahu výuky na základní škole zaměřuje pozornost na výstupy výuky. 
Nemáme zde záměr předložit systematizovaný přehled generalizací, ale hodláme dodržet vlastnosti generalizace, viz $(3$, s. 63): generalizace není absolutní (existují výjimky a záludnosti), -potvrzena bývá mnoha zkouškami, -vyjadřuje vztah mezi nejméně dvěma pojmy, -je obecněji platná.

Při formulaci generalizací vyjdeme ze „dvou skupin pramenü“, obvyklých V oborové didaktice. Jsou to prameny odborné, související se zákonitostmi techniky, dále prameny didaktické, popřr. související s praxí výuky.

\section{Prameny odborné, související se zákonitostmi techniky}

Každá technologie, technika popř. činnost s jakoukoli technikou musí respektovat zákonitosti techniky, vymezují prostor pro možná řešení a rozhodování. Lze tedy předpokládat souvislost zákonitostí techniky a generalizací ve výuce o technice. Problematiku tzv. základních zákonitostí techniky rozpracoval $\mathrm{H}$. Wolffgramm, mj. v publikaci (4). V souladu s ním nejprve uvedeme čtyři nejvýznamnější zákonitosti techniky, označeny jsou čísly 1 až 4:

\section{A. Jednota přirodnich a společenských} souvislostí v technice

Každý technický objekt, systém a postup spočívá $\mathrm{v}$ účelném využití prírodních pochodů, jevů, zákonitostí, je to relativně zjevné. Společenské a humánní souvislosti techniky se takto výrazně neprojevují, jejich působení je však účinné. Zatímco př́rodní zákonitosti vymezují možný prostor technických řešení, volba, objem i tempo vytváření a užívání techniky jsou závislé právě na společenských a lidských potřebách, možnostech, náladách, módě aj. Jednotlivé př́rodní a společenské zákonitosti jsou v technice ve vzájemném spolupůsobení.

\section{B. Determinovanost (předurčenost) techniky.}

Technika vznikla jako prostředek dosahování cílů a účelů. Základní otázkou i prŕstupem $\mathrm{v}$ technice je proto otázka: pro co, $\mathrm{k}$ jakému účelu je technika vytvořena a určena? Technika má být účelná. Smysl techniky není tedy v technice, leží „nad technikou“, v oblasti potřeb člověka či společnosti. Základní logický vztah v technice je proto vztah účel - prostředek, regulován musí být dalšími normami či hledisky společenskými i prrírodními.
C. Komplexní charakter techniky.

Zpravidla existuje značný počet působících př́rodních a společenských zákonitostí $\mathrm{v}$ technice. Zanedbání kterékoliv z nich může způsobit škody.

\section{Mnohost možností technických řešení.}

Technika disponuje možností většího počtu v podstatě správných řešení určité technické úlohy (v důsledku mnohosti souvislostí techniky je obtížné stanovení zcela optimálního řešení, o některých „větších“ technických řešeních se vedou dlouhé diskuse). Při činnosti s technikou bývá „více možností“.

Kromě základních zákonitostí techniky působí nespočet dalších technických zákonitostí. Z textu popisujícího „odbornou skutečnost“ nebudeme generalizace formulovat, analogicky $\mathrm{k}$ tomu, že zacílení, obsah i procesní stránka výuky mají prioritně vycházet $\mathrm{z}$ možností, zkušeností a potřeb žáka a jeho rozvoje, tedy z pedagogických aspektů. Až následně je třeba respektovat hlediska oborová, zejména ve všeobecném vzdělávání. Na základě uvedených technických zákonitostí se jako nesporné při formování generalizací jeví spojování „technických řešení“ se společenskými, humanitními i př́rodovědnými okolnostmi (to nabízí značné výchovné možnosti výuky o technice), je nezbytné zvažovat způsob i oprávněnost použití techniky vzhledem $\mathrm{k}$ účelu (stojí to za to, má to smysl?), nezanedbávat žádný aspekt činnosti $\mathrm{s}$ technikou. Formulace generalizací tedy budeme $\mathrm{v}$ dalším vyvozovat především $\mathrm{z}$ pedagogických zdrojů, tyto generalizace budou v souladu se zákonitostmi techniky.

\section{Prameny didaktické popř. související s praxí výuky}

Využijeme publikaci (3, s. 52-86), stat' (5), monografii (6) a RVP pro ZV (1).

V publikace M. Pasche (3, s. 55-65) jsou uvedeny podnětné príklady generalizací, my této skutečnosti využijeme a budeme usilovat o analogické formulace, což přispěje alespoň $\mathrm{k}$ dodržení jejich formální správnosti. Pro obecně technické předměty budou tyto formulace (původně byly zaměřeny na ekonomické nebo výukové souvislosti) relativně široké. Jde o tyto generalizace:

- Technická rozhodnutí by měla přinášet užitek uspokojením potřeb. 
- Otázka, zda zvolené řešení uspokojuje naše potřeby, je vždy oprávněná.

- Otázka, které potřeby hodláme vlastně uspokojovat, je na počátku činnosti s technikou nezbytná.

- Vždy je třeba zvažovat, zda lze technické řešení bez rozpaků přijmout, zda nemá „vedlejší negativní účinky“.

- Každé technické rozhodnutí je spojeno s náklady (práce, peníze, materiály, energie, možné souvislosti s životním prostředím atp.).

- Přijetí jednoho technického rozhodnutí či řešení omezuje možnost využití dalších.

- Při technických rozhodnutích je třeba dodržovat zákonitosti (pravidla, respektovat zvláštnosti) techniky, výsledky věd př́rodních a hlediska společenská a humanitní.

- Dodržování obecných i konkrétních zákonitostí techniky je třeba spojovat $\mathrm{s}$ jejich tvořivým uplatněním.

- Zvládnutí činnosti se složitou technikou vyžaduje určitý zácvik (čas).

- V př́ípadě dobrého chápání funkce a konstrukce techniky uživatelem lze očekávat lepší průběh činnosti s technikou.

- Seznámení se s konkrétními pravidly užívání, např. návodem, vede $\mathrm{k}$ lepším výsledkům, k efektivnímu využívání techniky.

Generalizace uvedené v (3) evokují i méně obecné adekvátní formulace, např.

- Jestliže si firma nebo značka vedla v minulosti dobře, lze očekávat dobrý produkt nebo službu.

- Zlepšení jedné mechanické vlastnosti materiálů způsobuje často zhoršení jiné vlastnosti.

- Kovy jsou velmi dobrými vodiči tepla (podobně elektrického proudu).

- Kovy se při zahřívání rozpínají.

Stat' významných odborníků J. Stoffy a M. Šefary (5), předkládajících vizi technické výchovy třetího tisíciletí, prezentuje $\mathrm{s}$ tím související postuláty, obsah i souvislosti př́pravy učitelů této výchovy. Lze formulovat tyto generalizace pro obsah výuky technických předmětů na ZS̆:

- Techniku je třeba chápat jako prostředek, který podle vưle člověka může pomáhat i škodit.

- Technika by sama o sobě neměla být účelem.

- Technika je výsledkem práce a pro práci je velká část techniky určena.

- K bezproblémovému životu V současné společnosti disponující technikou je potřebné běžně se vyskytující techniku zvládat (technická gramotnost).

- Technické poznání se neustále rozvíjí, jedinec si technické vzdělání musí také rozvíjet.

- Významnou součástí situací spojených

s užitím techniky je stabilita, udržitelnost

z hlediska bezpečnosti, životního prostředí, hygieny a zachování zdraví.

- Uživání techniky namnoze vyžaduje specifické znalosti a jejich tvořivé uplatnění.

- Poznání techniky navazuje na poznání řady společenských a př́rodních věd.

I na základě stati (5) lze formulovat generalizace poněkud méně obecné:

- Technickou výchovu člověka je třeba humanizovat.

- Komunikace související s technikou nastává mezi lidmi prŕmo nebo zprostředkovaně (prostřednictvím techniky). Je potřeba zvládat prostředky této komunikace (verbální, obrazové, popř. matematické).

- Komunikace může v jistém smyslu probíhat také mezi člověkem a technikou, která poskytuje uživateli informace (měřicí př́stroje, údaje na strojích, typické chování technických objektů v určitých situacích). Je potřeba zvládat také prostředky této komunikace (obrazové, popřs. matematické a dnes i verbální).

- Talent může být zaměřen i na různé oblasti techniky.

- Technika může být předmětem zájmů individua.

Monografie (6) se zabývá výchovou v obecně technickém vzdělávání. Z jejího textu lze vyvodit mj. tyto generalizace:

- Míra pozornosti věnovaná znehodnocování životního prostředí výrobou, užitím a odstraněním techniky se trvale zvyšuje.

- Technické vzdělání a uvažování o technice bez širších hledisek, zejména ekonomických, ekologických a bezpečnostních, nejsou úplné.

- Zdroje materiálů a energie jsou omezené.

- Práce může být zábavou i koníčkem.

- Každý má mít vysoké požadavky na kvalitu jím vykonávané práce.

- Ochrana výsledků práce je základní lidskou vlastností i povinností.

- Význam práce a techniky (technologií) v dějinách je podstatný.

- Je třeba minimalizovat vznik odpadu. 
generalizace:

Lze formulovat i méně obecné

- S odpadem je třeba co nejlépe zacházet (pořadí zde je: nepřipustit vznik odpadu, znovupoužít jej po úpravě, znovuvyužít jako materiál, spalovat pro energetické využití, sládkovat; to vše při zajištění ochrany prostředí).

- Reklama přináší užitečné i zkreslující informace.

- Nevhodným vlivům reklamy a módnosti je třeba nepodléhat.

- Existuje celá řada objektivních informací o technických produktech.

- Kvalita a hodnota techniky přímo souvisí.

- Estetické cítění a prožívání je možné a potřebné také ve vztahu $\mathrm{k}$ technice.

- Technika je zneužitelná i v souvislosti s informacemi (zneužití informačních technologií).

- Volba technických profesí je rozšířená, obvyklá a perspektivní.

- Při volbě profese je třeba zohlednit své možnosti i potřebnost dané profese a tato hlediska sladit.

- Obecnější př́íprava na profesi je výhodnější (perspektivnější) než př́íprava úzce zaměřená.

- Asi se během života budu rekvalifikovat.

RVP pro ZV (1, s. 14) udává jako rozhodující pro posuzování efektivnosti výuky kompetence, zejména klíčové kompetence. Učivo je chápáno jako prostředek $\mathrm{k}$ vytváření tzv. očekávaných výstupů směřujících $\mathrm{k}$ dosažení kompetencí. Školám je učivo jen doporučené pro rozpracování do jednotlivých ročníků nebo jiných časových úseků, až zařazením do ŠVP se stává závazné.

Formulace kompetencí jakožto základní cílové kategorie by však učivo mohla/měla „rámcově evokovat“, kromě toho, že učivo je stručně $v$ textu RVP uvedeno. Nejprve jsme se tedy zaměřili na to, zda z formulací očekávaných výstupů charakterizujících v RVP pro ZV klíčové kompetence (1, s. 14-17) lze „Vyčíst“ generalizace směřující $\mathrm{k}$ optimalizaci struktury obsahu ve výše uvedeném smyslu. Podle našeho zjištění tyto formulace směřují spíš ke způsobu výuky, $\mathrm{k}$ zaměření pozornosti učitele ve výuce, než př́mo $\mathrm{k}$ vymezení generalizací a to $\mathrm{i}$ velmi obecných. Např́klad z očekávaných výstupů ke klíčovým kompetencím k učení (1, s. 14) lze tak vyvodit význam práce $\mathrm{s}$ informacemi, význam termínů a prostředků grafické komunikace i kritického posouzení skutečnosti atp., ale formulovat generalizace ve výše uvedeném smyslu by bylo „odvážné“. Podobně očekávané výstupy pro klíčové kompetence pracovní (1, s. 17) jsou zaměřeny na dodržování pravidel (mj. bezpečné činnosti) i na schopnost adaptace na změněné podmínky, na př́ípravu pro budoucnost v profesi i v podnikání atp., ale generalizace odvozené i z této oblasti klíčových kompetencí by byly bud' velmi široké nebo nepodložené.

$\mathrm{S}$ relativně rámcovými formulacemi se setkáváme i v textu charakterizujícím vzdělávací oblast Člověk a svět práce (jako celek). Text postihuje širší spektrum pracovních činností a technologií, zaměřuje $\mathrm{k}$ získávání uživatelských dovedností a přispívá $\mathrm{k}$ vytváření životní a profesní orientace žáků tím, že „vychází z konkrétních životních situací, $\mathrm{v}$ nichž žáci přicházejí do př́mého kontaktu s lidskou činností a technikou $\mathrm{v}$ jejich rozmanitých podobách a širších souvislostech." Cílovým zaměřením je formulováno, čím přispívá vzdělávací oblast k rozvíjení klíčových kompetencí žáků, viz (1, s. 81-82). Jde mj. o pozitivní vztah $\mathrm{k}$ práci a ke kvalitě svých i společných výsledků práce, o poznání, že technika je spojena s pracovní činností, o chápání práce a pracovní činnosti jako př́ležitosti $\mathrm{k}$ seberealizaci, o orientaci $\mathrm{v}$ různých oborech lidské činnosti atp. I zde do značné míry platí výše uvedené o př́lišné neurčitosti těchto formulací pro podloženou konstrukci generalizací; generalizace nesporně vyplývající z této části textu RVP pro ZV byly ve stati již výše formulovány z jiných zdrojů.

Užší zaměření očekávaných výstupů lze očekávat $\mathrm{v}$ rámci jednotlivých tematických okruhů (1, s. 83-86), zde se zaměříme na okruhy technického charakteru. Jak dále uvidíme, obecnější generalizace vyvozené $v$ rámci jednoho tematického okruhu lze zpravidla aplikovat i v dalších tematických okruzích, což je samozřjmě pozitivní.

Výstupem Práce $\mathrm{s}$ technickými materiály má být mj. dodržování technologické kázně a bezpečnosti a ochrany zdraví při práci, řešení vhodného výběru materiálů, nástrojů a nářadí, plánování pracovní činnosti při užití technické dokumentace atp. Lze podloženě formulovat následující generalizace.

- Dlouhodobá bezpečnost a stabilita je základním požadavkem na techniku i technické činnosti a to zejména s ohledem na člověka.

- Dodržování pravidel (předpisů, zákonitostí, norem aj.) je při činnosti s technikou prvořadou podmínkou dobrého výsledku.

- Pro daný účel je třeba umět volit dostupné materiály a postačujícími vlastnostmi. 
- Umět si správně zvolit bezpečný nástroj pro technickou činnost je základní podmínkou úspěšného výsledku.

- Volba nástrojů závisí významně na vlastnostech objektů činnosti (vlastnosti materiálů, konstrukce techniky atp.).

Tematický okruh Design a konstruování je zaměřen na práci $\mathrm{s}$ technickou dokumentací, podle níž žák sestaví model, na práci s konstrukčními prvky a na jejich funkčnost, nosnost a stabilitu, montáž a demontáž i na oblast bezpečnosti práce. Obdobný charakter výstupů (správné zacházení s nástroji, údržba, práce dle návodu, bezpečnost a hygiena) lze spatřovat i v tematickém okruhu Provoz a údržba domácnosti, proto dále uvedené generalizace budou společné.

- Patř́ k potřebným dovednostem umět odhadnout, jaké zatížení snese užívaná technika sohledem na její rozměry, tvar a vlastnosti materiálů, $z$ nichž je vyrobena.

- Technika nebo technické činnosti nejprve „existují v představě“ tvůrce, zpravidla jsou přiměřenými prostředky vyjádřeny, teprve potom jsou realizovány (nebo také nejsou).

- Znalost prostředků pro vyjádření i přijetí technických myšlenek (slovní, grafické) je znalostí potřebnou $\mathrm{v}$ dnešním světě plném techniky a komunikace.

- Dobrá konstrukce je jako jiné „úspěšné věci v životě“ přehledná, pokud možno jednoduchá, ekonomická, estetická a funkční i pro delším používání.

Tematický okruh Svět práce má specifické a významné zacílení, zvyšovat orientaci žáka v pracovních činnostech vybraných profesí i jeho připravenost posoudit své možnosti při rozhodování o volbě vhodného povolání či profesní prrípravy, při tom využít profesní informace a poradenské služby pro výběr vhodného vzdělávání. Zásadní je také schopnost žáka prezentovat svou osobu při vstupu na trh práce.

- Vždy si klad’me otázku, zda je technika nebo činnost s technikou (+ technická profese) opravdu potřebná a $\mathrm{k}$ čemu (zde je třeba upř́ímnost).

- Jen na základě informací ze spolehlivých zdrojů lze odpovědně volit budoucí profesi.

- Pro volbu povolání je třeba dobře posoudit sám sebe, opak se nevyplatí.

- Je třeba být reálný při zvažování místních podmínek pro volbu povolání a brát do úvahy budoucí vývoj.
Je třeba umět výstižně a přesvědčivě mluvit a psát o sobě, o svých záměrech, zájmech i potřebách tak, abych nabízel své možnosti.

\section{K významu pojmů a faktů pro „výuku generalizací"}

Žákem osvojené generalizace se nezbytně musí opírat o související pojmy a fakta, všechny tyto kategorie jsou pro výuku významné, jak konstatoval J. Bruner (3, s. 54). Jinak mohou vzniknout nesprávné, chybné generalizace. Uvedeme pro představu některé běžně se vyskytující nesprávné generalizace (chybná obecná tvrzení) se „stručným faktickým vysvětlením“. Zde právě neznalost správných faktů vedla $\mathrm{k}$ nesprávné generalizaci, provedené jen na základě „odhadu či společenských nálad“.

- Tvrdé dřevo má větší výhřevnost než měkké dřevo.

Omyl vzniká vzhledem $\mathrm{k}$ větší hustotě tvrdého dřeva. Určitý objem měkkého dřeva má menší hmotnost než stejný objem dřeva tvrdého. Výhřevnost u tuhých a kapalných paliv je udávána na $1 \mathrm{~kg}$ paliva (u plynných na $1 \mathrm{~m}_{\mathrm{N}}^{3}$ ), proto $\mathrm{v}$ tabulkách udávajících výhřevnost můžeme vidět údaj pro dřevo vlhké a dřevo suché, ne pro dřevo měkké a dřevo tvrdé (7).

- Při spalování komunálního odpadu by do ovzduší vstupovalo mnohonásobně více škodlivin než při spalování obvyklých paliv.

Spalováním komunálního odpadu skutečně vzniká velké množství škodlivin. Současné systémy čištění spalin ale umožňují dosažení emisí z procesu energetického využívání odpadu na úrovni emisí ze spalování zemního plynu, považovaného za „čisté palivo“ (8). Proto mohou být nejpřísnější emisní limity stanoveny pro spalování odpadů. U jiných paliv se nesleduje všudypř́itomný obsah těžkých kovů, ani dioxiny, které vznikají při jakémkoliv spalovacím procesu (9).

Situace, kdy fakta jsou upravována, aby odpovídala generalizacím, by se neměly týkat obsahu výuky technických předmětů.

\section{Vnášení generalizací do výuky a fixace jejich osvojení \\ Podobně jako osvojování klíčových} kompetencí se děje převážně při činnostech s konkrétním obsahem, také generalizace, kromě toho, že jsou formulovány a zdůvodněny, mají být „deduktivně“ uplatňovány $\mathrm{v}$ technických činnostech ve výuce. B. Meier (10) doporučuje výuku inovativního obsahu spojovat s praktickými činnostmi zadáváním stále 
náročnějších úloh, řešených kooperujícími žáky, analogicky je treba pracovat s generalizacemi.

Také pro fixaci osvojení generalizací lze spatřovat plnou možnost využití postupů směřujících dle $\mathrm{B}$. Meiera $\mathrm{k}$ tomuto cíli. Jsou to:

Opakování - jde o konsolidaci a reaktivaci znalostí; jde tedy o činnost s dříve osvojovanými obsahy $\mathrm{v}$ podobě blízké osvojenému. Př̀i opakování tedy dochází $\mathrm{k}$ reprodukci dříve osvojených poznatků, uplatňuje se křivka zapomínání.

Procvičování - jde o zlepšování možností žáka konat činnosti, tedy o prohlubování dovedností v širokém smyslu. Procvičování je v úzkém vztahu k opakování, jde však při něm o průběh jednání, nácvik správné činnosti. Zde hrozí dril (zejména při nedostatku samostatnosti žáka), $\mathrm{v}$ technických předmětech na ZŠ jen výjimečně oprávněný. $\mathrm{V}$ př́padě generalizací jde o nácvik i analýzu jejich uplatnění v typických situacích.

Systematizace znalostí - jde o organizaci znalostí i způsobilostí jednat do přehledných, logických a zdůvodněných systémů. Při této činnosti učitele připravované již v preinteraktivní fázi výuky, vznikají schémata znalostí jakožto reprezentace skutečnosti; jsou oceňována konstruktivisty.

Užití, aplikace - zajišt'uje vysokou disponibilitu znalostí a dovedností, směřuje se $\mathrm{k}$ analogickému i variabilnímu, k novým situacím. Dominantními pojmy zde jsou transfer osvojeného a vytváŕení kompetencí.

Základní postupy a význam systematizace $\mathrm{a}$ také aplikace považujeme $\mathrm{v}$ prípadě generalizací zjevné, upozorn̆ujeme na význam generalizací jako kriteria správné činnosti.

\section{Závěry}

$\mathrm{Ve}$ stati jsme předkládali formulaci generalizací, ne systematicky, ale s ohledem na návodnost způsobu formulace generalizací jakožto zobecňujících výstupů výuky, které by si měl žák dlouhodobě podržet a které tvoři jakási schémata $v$ jeho další činnosti (ve smyslu konstruktivismu). Snažili jsme se o „užitečnost“ těchto generalizací a také o zaměření pozornosti na tuto problematiku smyslu a zacílení výuky. Uvědomili jsme si, že podobně jako při formulaci kompetencí v RVP je i při formulaci generalizací pozornost soustředěna na výstupy výuky, které by si měl žák dlouhodobě podržet. Formulované kompetence a generalizace by pro tutéž výuku neměly být $\mathrm{v}$ nesouladu.
Text RVP pro ZV se ale pro tvorbu generalizací ukázal prínosný až $\mathrm{v}$ částech spíš konkrétněji zaměřených, i tak nám poskytoval méně podnětů než jiné uvedené publikace, vybrané do značné míry nahodile. Je tedy třeba vzít do úvahy, že tento „velmi rámcovýc text, který se jinak může osvědčovat, není v tomto směru postačující. Jako potřebné se tedy jeví využívání jiných metodických materiálů, odborných textů, vzorových úloh atp. Ukazuje se také nezbytnost dobrého didaktického zvládnutí oboru učitelem, dále význam některých oblastí teorie didaktiky, jako je teorie zaměřená na formulaci smyslu a cílů výuky, teorie didaktické transformace a integrace poznání, didaktické znalosti základních zákonitostí techniky aj. $\mathrm{Na}$ učitele technických předmětů na ZŠ klade tato situace značné požadavky, tím spíš, že učitel této aprobace je na škole sám. Poslední část stati ukazuje možnost snadného vzniku nesprávných generalizací.

Zatímco vidíme pochopitelnou snahu u př́rodovědných předmětů rozšiřovat své aplikace do prostředí techniky (uměle vytvořeného světa), předmětům, které se tomu prioritně a komplexně věnují, je věnována nepochopitelně malá pozornost. Také proto jsme prezentovali jen generalizace prímo spojené $\mathrm{s}$ technickou výchovou, ne související pouze $\mathrm{s}$ prírodními nebo společenskými vědami, např. nejobecnější zákony prrírodních věd atp.

\section{Literatura:}

1. Rámcový vzdělávací program pro základní vzdělávání [online] - [cit. 2009-02-12]. Dostupné na WWW: <http://www.rvp.cz/sekce/58>.

2. Webová stránka 1. ZŠ Frýdek-Místek [online] - [cit. 2009-02-12]. Dostupné na WWW: http://www.1zsfm.cz/ucebni-plany-a-osnovy2008-2009

3. PASCH, M. aj. Od vzdělávacího programu $k$ vyučovaci hodině. Praha: Portál, 1998. ISBN 80-7178-127-4.

4. WOLFFGRAMM, H. Allgemeine Technologie. Band 1. Teil 1. Hildesheim : Verlag Franzbecker, 1994. ISBN 3-88120-241-2.

5. STOFFA, J. a ŠEFARA, M. Naša vízia technickej výchovy tretieho tisícročia. In Modernizace výuky $v$ technicky orientovaných oborech a predmètech : Sbornik I. Olomouc : Vydavatelství Univerzity Palackého v Olomouci, 1999, s. 10-17. ISBN 80-244-0051-0.

6. KROPÁČ, J. a CHRÁSKA, M. Výchova v obecně technických predmětech. Olomouc : 
Univerzita Palackého, Pedagogická fakulta, 2004. ISBN 80-244-0897-X.

7. Výhřevnosti a měrné jednotky palivového dreva [online] - [cit. 2009-03-09]. Dostupné na WWW:

info.cz/t.py?t=16\&i $=12 \& \mathrm{~h}=38$ http://www.tzb-

8. HYŽÍIK J. Energetické využívání odpadu je nepostradatelné. Odpady, 2008, roč. 18, č.1, s. 21-22. ISSN 1210-4922.

9. PEROUTKA K. a SUZOVÁ J. Znečištující látky z energetického využití odpadů - fakta a mýty. Odpady, 2008, roč. 18, č. 4, s. 20-22. ISSN 1210-4922.

10.MEIER, B. Festigen durch Wiederholen, Eben, Systematisieren, Anwenden. Unterricht Arbeit + Technik, 2008, Jahrgang 10, Heft 40, S. 62. ISSN 1438-8987.
Doc. PaedDr. Jiří Kropáč, CSc., PhDr. Jitka Plischke, PhD.

Univerzita Palackého v Olomouci,

Pedagogická fakulta, Žižkovo nám. 5, 77140

Olomouc, tel. +420 585635805 , e-mail:

kropac@pdfnw.upol.cz

www pracoviššě: http://www.kteiv.upol.cz/

Ing. Jiř́i Kropáč (student DSP), Vysoké učení technické v Brně, Fakulta strojního

inženýrství, Ústav procesního a ekologického inženýrství, Technická 2, 61669 Brno, tel. +420541142322 ,

e-mail: ykropa02@stud.fme.vutbr.cz, www pracoviště:

http://www.upei.fme.vutbr.cz/cs/index/ 